\title{
An arginine to lysine substitution in the bZIP domain of an opaque-2 mutant in maize abolishes specific DNA binding
}

\author{
Milo J. Aukerman, ${ }^{1}$ Robert J. Schmidt, ${ }^{1,2}$ Benjamin Burr, ${ }^{3}$ and Frances A. Burr ${ }^{3}$ \\ ${ }^{1}$ Department of Biology, C-016, and Center for Molecular Genetics, University of California at San Diego, La Jolla, \\ California 92093 USA; $^{3}$ Biology Department, Brookhaven National Laboratory, Upton, New York 11973 USA
}

\begin{abstract}
The opaque-2 (o2) locus in maize encodes a transcription factor involved in the regulation of zein storage proteins. We have shown previously that the 02 protein contains a leucine zipper domain that binds to promoters of 22-kD zein genes. In this paper we characterize an EMS-induced 02 allele, $02-676$, that causes a $50 \%$ reduction in zein. We have found that the $02-676$ mutant protein does not show specific recognition of zein promoter fragments because of the substitution of a lysine residue for an arginine residue within the bZIP domain of 02-676. This particular arginine is conserved within the bZIP domains of all mammalian, fungal, and plant DNA binding proteins of this class. The correlation between this mutation in 02 and the altered pattern of zein expression strongly suggests that $\mathrm{O} 2$ regulates transcription of certain members of the zein multigene family through direct interaction with the zein promoters and not through the transcriptional activation of some other regulator of zein gene expression.
\end{abstract}

[Key Words: Transcription factor; Zea mays; seed storage protein; bZIP domain; DNA binding; zein genes]

Received July 13, 1990; revised version accepted November 21, 1990.

Maize plants carrying an opaque-2 (02) mutation have seeds with an opaque, rather than glassy, appearance that is attributable to a dramatic reduction in the zein storage proteins. Zeins can be resolved by isoelectric focus (IEF)SDS two-dimensional gels into two major size classes of 19 and $22 \mathrm{kD}$ /Gianazza et al. 1976; Hagen and Rubenstein 1980). Zein genomic and cDNA clones encoding proteins of both the 19 - and $22-\mathrm{kD}$ classes have been isolated and sequenced. Although they are clearly related, zein genes expressing proteins of the $22-\mathrm{kD}$ size class are distinct from those expressing members of the 19-kD size class (Burr et al. 1982; for review, see Heidecker and Messing 1986; Rubenstein and Geraghty 1986). Plants homozygous for o2 typically show a 50$70 \%$ reduction in zein (Mertz et al. 1964; Nelson 1979), especially in the polypeptides of the $22-\mathrm{kD}$ zein class (Soave et al. 1976; Burr and Burr 1982b). This reduction appears to result from a lower rate of transcription of zein genes, particularly those of the $22-\mathrm{kD}$ class (Kodrzycki et al. 1989).

The $\mathrm{O} 2$ gene has been cloned by transposon tagging (Schmidt et. al. 1987; Motto et al. 1988). The sequence of the cDNA (Hartings et al. 1989; Schmidt et al. 1990) suggests that the $\mathrm{O} 2$ gene encodes a polypeptide containing a "leucine zipper" dimerization/DNA-binding (bZIP) domain characteristic of a class of mammalian and fungal transcription factors (Landschulz et al. 1988a). This

${ }^{2}$ Corresponding author.
bZIP domain consists of a heptameric repeat of leucines with an adjacent, amino-terminal cluster of basic amino acids. The leucine repeat is proposed to function as a dimerization interface, while the highly conserved basic region directly contacts a DNA target site (Landschulz et al. 1988a). Our previous paper additionally showed that the bZIP domain of the O2 protein could bind specifically to the promoter region of a $22-\mathrm{kD}$ zein gene (Schmidt et al. 1990).

Here we characterize an ethylmethane sulfonate (EMS)-induced opaque-2 mutant allele, 02-676, for its effect on zein expression, and for the ability of its gene product to bind to zein promoters. Unlike the wild-type O2 protein, the $02-676$ protein does not display specific DNA binding in our in vitro assay. We have identified a single amino acid change within the basic domain of the $02-676$ gene product, arginine to lysine, which is responsible for this phenotype. This particular arginine is completely conserved in all bZIP proteins thus far isolated and is also found in the corresponding position of the basic domain of many helix-loop-helix and Myc-related proteins. Conservative amino acid substitutions at an asparagine residue near this invariant arginine in the basic domain also abolished the DNA-binding activity of the $\mathrm{O} 2$ protein. These experiments indicate that both amino acids play an essential role in the DNA-binding function of the $\mathrm{O} 2$ protein and that even conservative changes cannot be tolerated at these positions in the bZIP domain. 


\section{Results}

The 02-676 and 02-R alleles have different effects on zein expression

The standard $02-R$ mutant allele typically causes a reduction of polypeptides in the $22-\mathrm{kD}$ class of zeins. We identified a novel opaque mutation from among 150 EMS-generated opaque mutants by screening for effects on zein synthesis by SDS-polyacrylamide gel electrophoresis. The new mutation had the opposite effect to that of the $02-R$ mutation; that is, it decreased the $19-\mathrm{kD}$ zeins to a greater extent than the $22-\mathrm{kD}$ zeins. From allelism tests between the new mutation and all known loci giving an opaque phenotype it was shown to be a recessive allele of the 02 locus and given the designation $02-676$. To ensure that the $02-676$ phenotype was not due to genetic background effects, the $02-676$ allele and the $02-R$ allele were backcrossed for six generations to three standard maize inbreds, W22, Oh43, and R802 (Fig. 1 ; Table 1). Table 1 shows the results of analyses of zein content in seed from three different inbred lines homozygous for the normal, the $02-676$, or the $02-R$ allele. In each of the inbred backgrounds, zein protein levels in the $02-676$ mutant are reduced by $30-60 \%$ relative to wild type, whereas zein levels are decreased by $60-80 \%$ in the $02-R$ allele.

The effect of the $02-R$ and $02-676$ alleles on zein expression can be better visualized by analyzing the zeins extracted from these mutants on two-dimensional IEF/

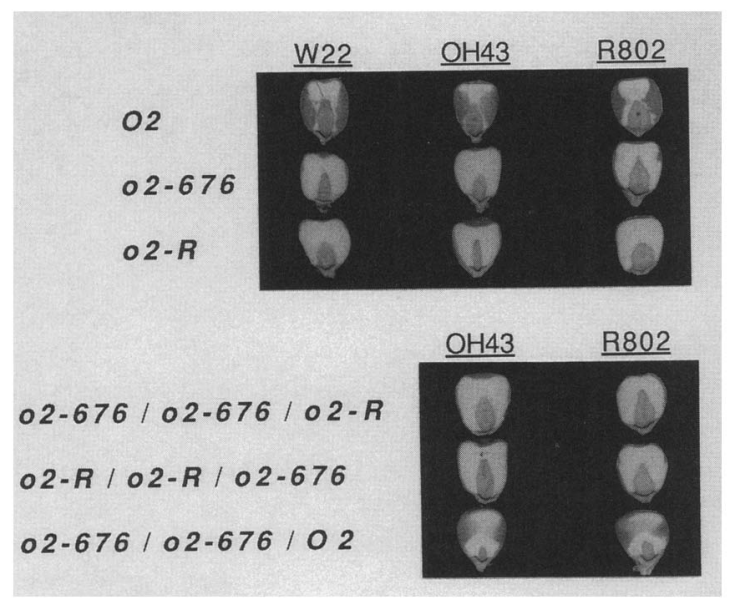

Figure 1. Kernel phenotypes of the three 02 alleles in different inbred backgrounds. (Top) Seeds cut longitudinally in half show the phenotype of the indicated 02 alleles after six generations of backcrossing to three standard inbreds, W22, OH43, and R802. The whitish, chalky endosperms in the 02 mutants contrast with the hard, vitreous endosperms so conspicuously apparent on either side of the starchy crown of the wild-type kernels. A portion of the embryo is apparent in the middle to lower center of each kernel. (Bottom) The phenotypes obtained after reciprocal crosses between $02-676$ and $02-R$ mutants and between $02-676$ and the normal 02 . The dosage of the 02 alleles in the triploid endosperm is indicated. The normal endosperm phenotype is obtained when a single normal $O 2$ allele is present, indicating that the $02-676$ allele is not codominant.
Table 1. Zein yields in different maize inbreds that were homozygous or heterozygous for the indicated alleles of 02

\begin{tabular}{lccc}
\hline & \multicolumn{3}{c}{ Milligrams of zein per gram of meal } \\
\cline { 2 - 4 } & $\mathrm{W} 22$ & $\mathrm{OH} 43$ & $\mathrm{R} 802$ \\
\hline $\mathrm{O} 2$ & 51 & 45 & 47 \\
$o 2-676$ & 20 & 31 & 27 \\
$02-R$ & 10 & 11 & 20 \\
& & $\mathrm{OH} 43$ & $\mathrm{R} 802$ \\
\hline $02-676 / 02-676 / 02-R$ & 20 & 22 \\
$02-R / 02-R / 02-676$ & 24 & 13 \\
$o 2-676 / 02-676 / 02$ & 40 & 44 \\
\hline
\end{tabular}

The top half shows yields from endosperms homozygous for the indicated alleles. The bottom half shows yields from heterozygous endosperms with the indicated triploid allelic combinations. Reciprocal crosses between $02-676$ and $o 2-R$ mutants in W22 were not performed. Values represent the average of at least three separate determinations.

SDS/polyacrylamide gels. Analyses of the three inbred lines produced similar results. Figure 2 shows the spectrum of zein polypeptides affected by the two different 02 mutant alleles in the maize inbred lines W22 and R802. In endosperms homozygous for the $02-R$ allele, expression of the $22-\mathrm{kD}$ zeins is dramatically reduced, while a few members of the $19-\mathrm{kD}$ zeins are still present. The expression of these $19-\mathrm{kD}$ zein polypeptides can occur in the absence of $\mathrm{O} 2$ protein because the $02-R$ allele does not produce detectable O2 mRNA (Schmidt et al. 1987). Unlike $02-R$, the $02-676$ mutant expresses members of both zein classes (Fig. 2). Although the overall zein protein level is reduced in this mutant when compared to the wild-type allele (Table 1), the spectrum of proteins produced is more similar to that of the normal $\mathrm{O} 2$ allele than it is to the $02-\mathrm{R}$ allele.

To demonstrate that the effects of the 02 and $02-676$ mutations are at the level of zein gene transcription, we performed RNA slot blot analyses of the zein transcript levels from each of the three 02 homozygotes. As can be seen in Figure 3, transcript for the $22-\mathrm{kD}$ class of zeins is reduced in both 02 mutants relative to wild type. The reduction is more severe in $02-R$ than in $02-676$. This result is in good agreement with what would be expected for the $22-\mathrm{kD}$ zein transcript levels on the basis of the results of the zein yield data and the two-dimensional gel analysis; namely, that the effect of the $02-676$ mutation on $22-\mathrm{kD}$ zein gene expression is not as severe as seen for the $o 2-R$ allele.

Because the levels of some of the $19-\mathrm{kD}$ zein proteins appeared reduced relative to the $22-\mathrm{kD}$ zeins in $02-676$, we asked whether this was the consequence of reduced transcription in this class of zeins. The same slot blot was reprobed with two cDNA clones that recognize transcripts from two distinct subfamilies of $19-\mathrm{kD}$ zein genes (subfamilies 2 and 3; Rubenstein and Geraghty 1986). One of these, B41, is more severely reduced in $02-676$ than in $02-R$, whereas the expression of the other, B54, is 


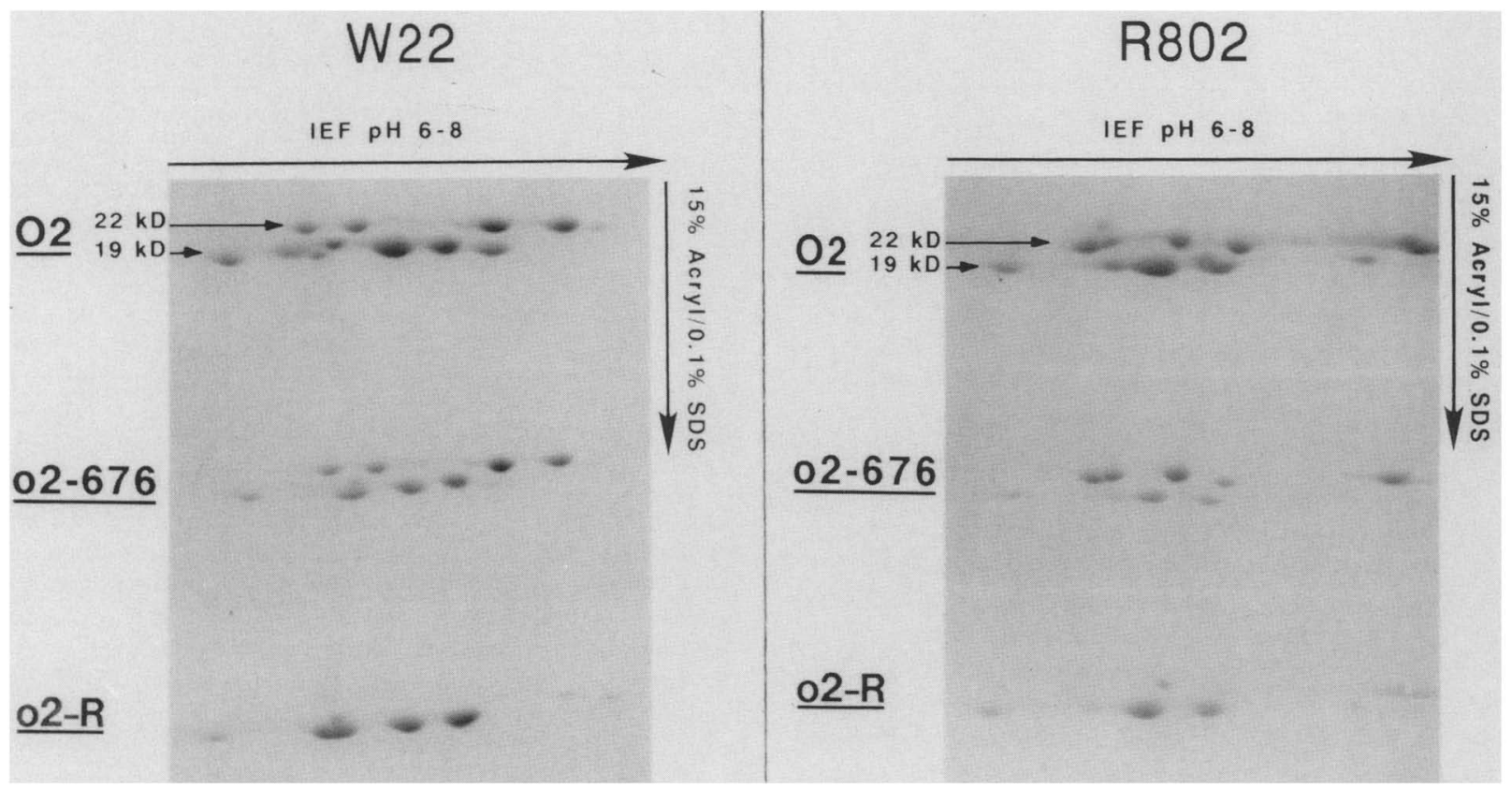

Figure 2. Two-dimensional gel profiles of the 19- and 22-kD zein polypeptides from seed homozygous for $02,02-676$, or $02-R$. The effects of these mutations are shown for two different inbred backgrounds, W22 and R802. The $02-676$ mutant allele does not reduce $22-\mathrm{kD}$ zein protein levels as severely as the $02-R$ allele does. Zeins were alcohol-extracted from wild-type or mutant endosperms, and separated by charge in the first dimension (IEF), followed by molecular mass separation in the second dimension (SDS-PAGE).

more similar in the two mutants. These results show that the transcription of at least one member of the 19$\mathrm{kD}$ zein gene family is more severely reduced in $02-676$ than in $o 2-R$.

To determine whether the $02-676$ allele produced normal amounts of an O2-specific mRNA, an RNA blot hybridization analysis was performed. Using a $0.6-\mathrm{kb}$ EcoRI fragment of the $\mathrm{O} 2$ cDNA as a probe, we detected a prominent $\mathrm{O} 2$ message in the endosperm of plants homozygous for the wild-type and $02-676$ alleles (Fig. 4). In endosperm homozygous for the $02-R$ allele, this message is completely absent (Fig. 4), confirming our previous analysis of this allele (Schmidt et al. 1987). The similar size and abundance of the $02-676$ and wild-type transcripts suggests that the phenotype of the $02-676$ mutation is not a consequence of reduced 02 gene expression. Further characterization of the mutation focused directly on the $02-676$ gene product. An o2-676 cDNA clone was isolated and used to generate mRNA for translation in a wheat germ translation system. The in vitrogenerated o2-676 polypeptide had a similar mobility on SDS-polyacrylamide gels to the normal $\mathrm{O} 2$ protein (data not shown). These results suggested that the $02-676$ allele makes an $\mathrm{O} 2$ protein in vivo that is defective in some function necessary for zein gene activation.

An arginine residue in the basic domain of the $\mathrm{O} 2$ protein is changed to lysine in $02-676$

Previous work has established that the normal O2 protein contains a bZIP domain that can bind to zein pro- moters (Schmidt et al. 1990). It was thus possible that the defect in the $02-676$ protein was located within the bZIP domain. We investigated this possibility by sequencing a StuI-SalI restriction fragment of the 02-676 cDNA (nucleotides 571-855 in O2; Schmidt et al. 1990) that encompasses the bZIP domain. Comparison of the $\mathrm{O} 2$ and o2-676 cDNA sequences revealed a G-to-A transition that changes an arginine to a lysine in the basic region of the o2-676 bZIP domain (Fig. 5). Sequence alignment of the basic domains of several bZIP proteins reveals that most of the arginine and lysine residues in this region are not completely conserved and thus may be interchangeable at many positions. The particular arginine that is substituted in the $02-676$ allele is unique in that it is completely conserved in all bZIP proteins sequenced thus far (Fig. 5; Vinson et al. 1989). This arginine is also conserved within the corresponding basic domains of the helix-loop-helix and Myc-related protein family (Prendergast and Ziff 1989).

\section{The 02-676 protein cannot bind specifically to zein promoter fragments}

We have recently demonstrated that the $\mathrm{O} 2$ protein can bind to $22-\mathrm{kD}$ zein gene promoter fragments in vitro and that the bZIP domain alone was sufficient for this interaction (Schmidt et al. 1990). Because the arginineto-lysine change in the mutant $02-676$ protein is in the bZIP region, it seemed likely that this mutation affected the ability of the protein to recognize zein promoters. We tested this idea by constructing a fusion of the bZIP mo- 


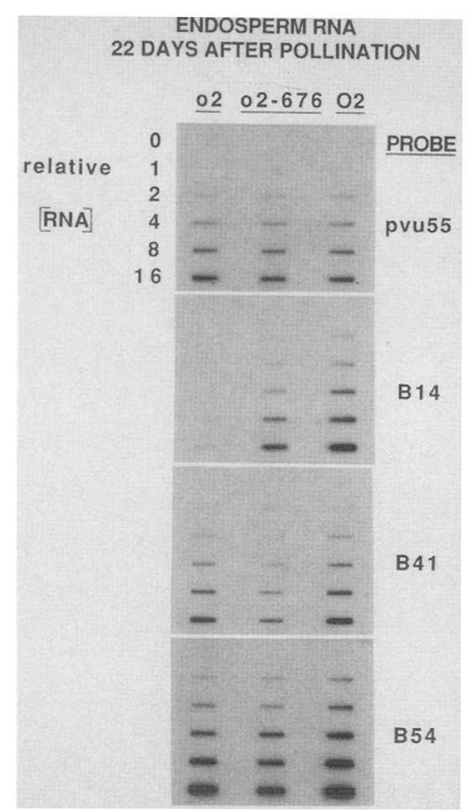

Figure 3. Analysis of zein transcripts in the $02,02-676$, and $02-R$ mutants. An autoradiogram of slot blots of total RNA from R802 endosperms homozygous for the indicated o2 alleles. Approximately equal amounts of mRNA are present for each genotype, as indicated by probing with pvu55 (top). This probe (Burr and Burr 1982a) is a fragment of the maize sucrose synthetase gene, an abundant enzyme involved in starch biosynthesis. The first two subjacent panels show the same blot reprobed with the zein cDNA probes B14 and B4l. (Bottom) A separate blot that was loaded with the same amounts of RNA as at top and probed with B54. The B14 probe is a cDNA clone encoding a $22-\mathrm{kD}$ zein; both $\mathrm{B} 4 \mathrm{l}$ and $\mathrm{B} 54$ probes are cDNAs belonging to the $19-\mathrm{kD}$ zein class (Burr et al. 1982). Hybridizations were performed at high stringency to minimize hybridization between classes. The relative concentrations of RNA per slot are indicated at top left.

tif of the $02-676 \mathrm{cDNA}$ with the lacZ gene (Rüther and Müller-Hill 1983), and assaying the resultant fusion protein for DNA-binding activity.

Upon induction with isopropylthiogalactoside (IPTG), Escherichia coli cells containing a lacZ/o2-676 bZIP fusion construct expressed a protein with an apparent molecular mass of $130 \mathrm{kD}$ that was detectable by SDSPAGE (Fig. 6A, lane 4a). A protein consisting of the wildtype bZIP region fused to $\beta$-gal displayed a similar mobility (Fig. 6A, lane 3a). These two proteins are referred to as the $02-676 \mathrm{bZIP}$ and O2 bZIP fusion proteins, respectively. Another fusion of almost the entire coding sequence of the $\mathrm{O} 2$ cDNA to lac $Z$ produces a polypeptide, termed the $\mathrm{O} 2$ fusion protein, of at least $162 \mathrm{kD}$ (Fig. 6A, lane 2a). To assay for DNA binding, each protein was immunoprecipitated out of crude bacterial extracts with a monoclonal antibody against $\beta$-gal, and then incubated with labeled zein DNA. Specifically bound zein fragments were then recovered and analyzed (Schmidt et al. 1990).

As shown in Figure 6B, the $\mathrm{O} 2$ fusion protein binds to two labeled Sau3AI fragments of pZ-1B, a zein genomic clone that specifies a $22-\mathrm{kD}$ zein protein. When the same $\mathrm{O} 2$ fusion protein is incubated with another $22-\mathrm{kD}$ zein genomic clone, pZ-2BS, a single 200-bp fragment is bound (Fig. 6B). Sequence analysis shows that this fragment is identical to the 200-bp fragment of pZ-1B that is bound by the fusion protein (data not shown). Both 200bp sequences can be mapped to a region $\sim 300$ nucleotides upstream of the zein-coding sequences, within the promoter regions of their respective genomic maps (Fig. 6C). Although $\mathrm{O} 2$ binds a 500-bp element farther upstream in pZ-1B, this site is not present in pZ-2BS (Fig. 6C; G. Hoschek and R.J. Schmidt, unpubl.) nor in the sequence of any other published $22-\mathrm{kD}$ zein gene promoter (Spena et al. 1982; Langridge and Feix 1983; Kridl et al. 1984; Brown et al. 1986). When the O2 bZIP fusion protein is incubated with either pZ-1B or pZ-2BS fragments, a similar pattern of binding is seen (Fig. 6B, lanes 3).

Whereas the wild-type fusion proteins consistently show specific binding to the zein promoter fragments in our in vitro assay, the 02-676 bZIP fusion protein shows no significant binding (Fig. 6B, lanes 4 ). The inability to detect DNA binding by the o2-676 fusion protein in our in vitro-binding assay is not due to insufficient amounts of the $02-676 \mathrm{bZIP}$ protein in the assay; there was more 02-676 bZIP fusion protein utilized for the DNA-binding assay than there was of the O2 bZIP fusion protein (Fig. $6 \mathrm{~A}$, lanes $3 \mathrm{~b}$ and $4 \mathrm{~b}$ ).

The observed correlation between loss of DNA binding and substitution at the invariant arginine in the o2676 protein implies that this residue is essential for the DNA-binding activity of the $\mathrm{O} 2$ protein. If the substitution of lysine at the invariant arginine position is the only relevant change with respect to the DNA-binding phenotype, then changing this single residue back to arginine should restore wild-type binding. Site-directed

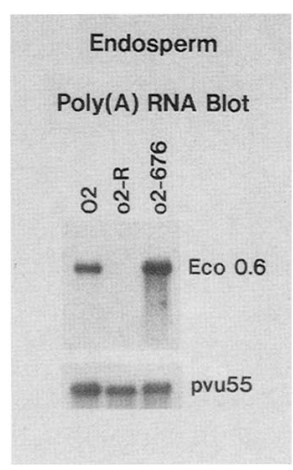

Figure 4. Northern blot analysis of O2-specific transcripts. Poly $(A)^{+}$RNA was extracted at 22 DAP from OH43 endosperms that were homozygous for the $O 2,02-R$, or 02.676 alleles. Approximately $2.5 \mu \mathrm{g}$ of poly $(\mathrm{A})^{+}$-enriched RNA was loaded in each lane. The $\mathrm{O} 2$ probe was a $0.6-\mathrm{kb}$ EcoRI fragment of the O 2 cDNA (Schmidt et al. 1990). The blot was stripped and rehybridized with pvu55, the sucrose synthetase probe, as a loading control. 
Figure 5. Comparison of the basic domains in $\mathrm{O} 2$ and o2-676 with several other bZIP proteins. The invariant arginine in the basic region is indicated with an asterisk, with the lysine substitution in $02-676$ designated in boldface. Only the first leucine (boldface) of the leucine heptad repeat is shown. The deduced amino acid sequence of the leucine heptad repeat (not shown) in 02-676 is identical to the sequence in O2 (Schmidt et al. 1990). The bZIP consensus is based on the consensus shown in Vinson et al. (1989). The letter B is used to designate positions in the basic region where either arginine or lysine is the predominant residue. The asparagine $(N)$ and arginine $(R)$ in the consensus sequence are completely conserved in all bZIP proteins described thus far and are shown boxed. Sources for sequences: $(\mathrm{O} 2)$ Schmidt et al. (1990); (Fos) Van Straaten et al. (1983); (FRA1) Cohen and Curran (1988); (JunB) Ryder et al. (1988); (c-Jun) Angel et al. (1988); (GCN4) Hinnebusch (1984); (CPC1) Paluh et al. (1988); (CREB) Gonzalez et al. (1989); (C/EBP) Landschulz et al. (1988b); (TGAla) Katagiri et al. (1989); (HBP1) Tabata et al. (1989).

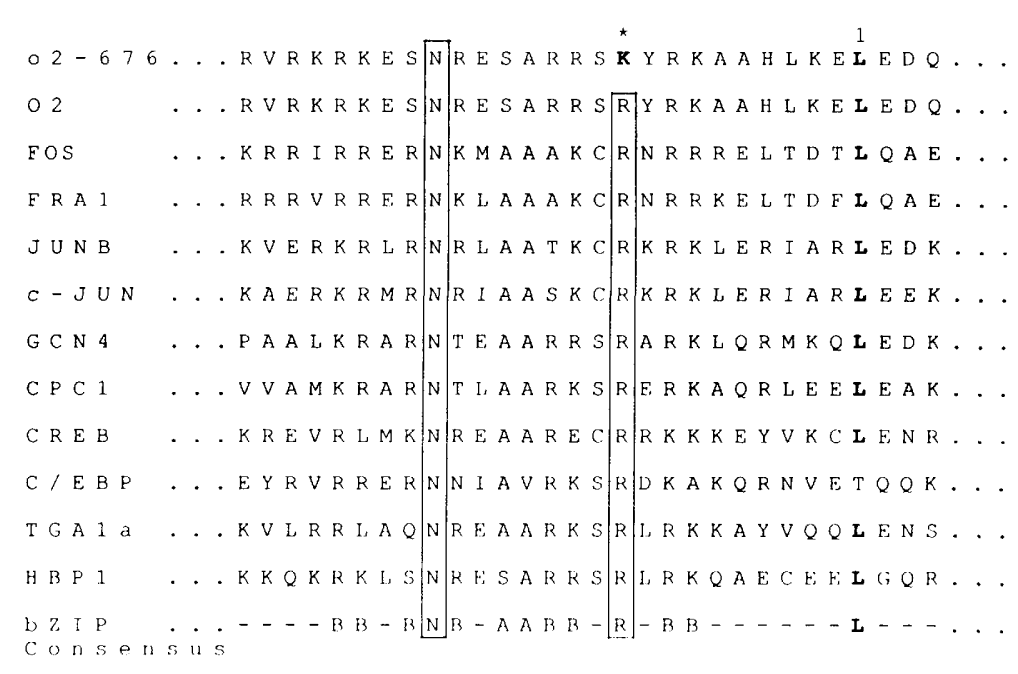

mutagenesis was used to reintroduce the invariant arginine codon at the position of the substituted lysine codon in the 02-676 cDNA. In-frame fusions to the lacZ gene were generated for the mutagenized template $102-$ $676 \mathrm{~K}-\mathrm{R}$ ) and also for the original o2-676 cDNA. On induction in E. coli, these two constructs both produced fusion proteins of a similar size $(>162 \mathrm{kD})$ to the $\mathrm{O} 2$ fusion protein described earlier (data not shown).

The original $02-676$ and $02-676 \mathrm{~K}-\mathrm{R}$ fusion proteins were tested for DNA binding by the immunoprecipitation assay. As indicated in Figure 7, the 02-676 fusion protein does not bind detectably to the 200-bp zein target fragment; however, the $02-676 \mathrm{~K}-\mathrm{R}$ fusion protein does bind to the target fragment. Comparison of the intensity of the radioactive band retained by $02-676 \mathrm{~K}-\mathrm{R}$ to that retained by the wild-type $\mathrm{O} 2$ fusion protein suggests that the affinities of these two proteins for the target fragment are similar, if not identical (Fig. 7). Thus, the reintroduction of the invariant arginine back into the 02-676 protein results in a complete restoration of wild-type DNA binding.

\section{Mutations at an invariant asparagine in the basic domain of $\mathrm{O} 2$ also abolish DNA binding}

Although the overall structure of the bZIP domain is conserved in proteins from a wide variety of organisms, there are only two residues within the domain that are completely conserved throughout the whole bZIP family. The arginine that is substituted in the $02-676$ protein represents one of these; the other is an asparagine residue located 8 amino acids amino-terminal to the invariant arginine (Fig. 5; Vinson et al. 1989). We reasoned that, similar to the invariant arginine, the invariant asparagine may play a critical role in DNA binding. To test this idea, we constructed three separate site-directed substitutions of varying severity /asparagine to glu- tamine, $\mathrm{N}-\mathrm{Q}$; asparagine to alanine, $\mathrm{N}-\mathrm{A}$; and asparagine to aspartic acid, N-D) at the asparagine codon in the wild-type cDNA. Fusions to $l a c Z$ were constructed as described previously, and the resultant fusion proteins were tested for DNA-binding activity.

As shown in Figure 7, none of the three proteins substituted at the invariant asparagine bind in any detectable fashion to the zein target DNA. Even a somewhat conservative change, asparagine to glutamine, is unable to bind, indicating a stringent requirement for an asparagine at this position to maintain DNA-binding activity.

Can the 02-676 protein show weak association with the zein promoter under less stringent conditions?

The 02-676 protein shows no affinity for the zein promoter fragment in vitro, yet the 02-676 mutation does not behave as a null allele in vivo (Table 1; Fig. 2), as would be expected if the $02-676$ mutant protein is incapable of binding to its target site. This implies that the o2-676 protein is partially functional in vivo. One explanation, then, for the partial functionality of the $02-676$ allele is that the $02-676$ protein binds weakly to zein promoters in vivo but that the conditions of our in vitro binding assay are too restrictive to detect this weak association. To detect weaker interactions of the $02-676$ fusion protein with the zein promoter fragment, we varied a parameter of the in vitro DNA-binding assay that is known to affect the capacity of proteins to bind to nucleic acid; namely, the concentration of $\mathrm{NaCl}$ (Desplan et al. 1985; Laughon et al. 1988). As $\mathrm{NaCl}$ in the binding reaction is lowered from $200 \mathrm{mM}$, the wild-type fusion protein binds nonspecifically to many fragments, but the 02-676 protein is unable to bind even nonspecifically at $20 \mathrm{~mm} \mathrm{NaCl}$ (Fig. 8). In addition, no specific interaction of $02-676$ with the zein promoter fragment was detected under conditions of decreasing amounts of nonspecific 


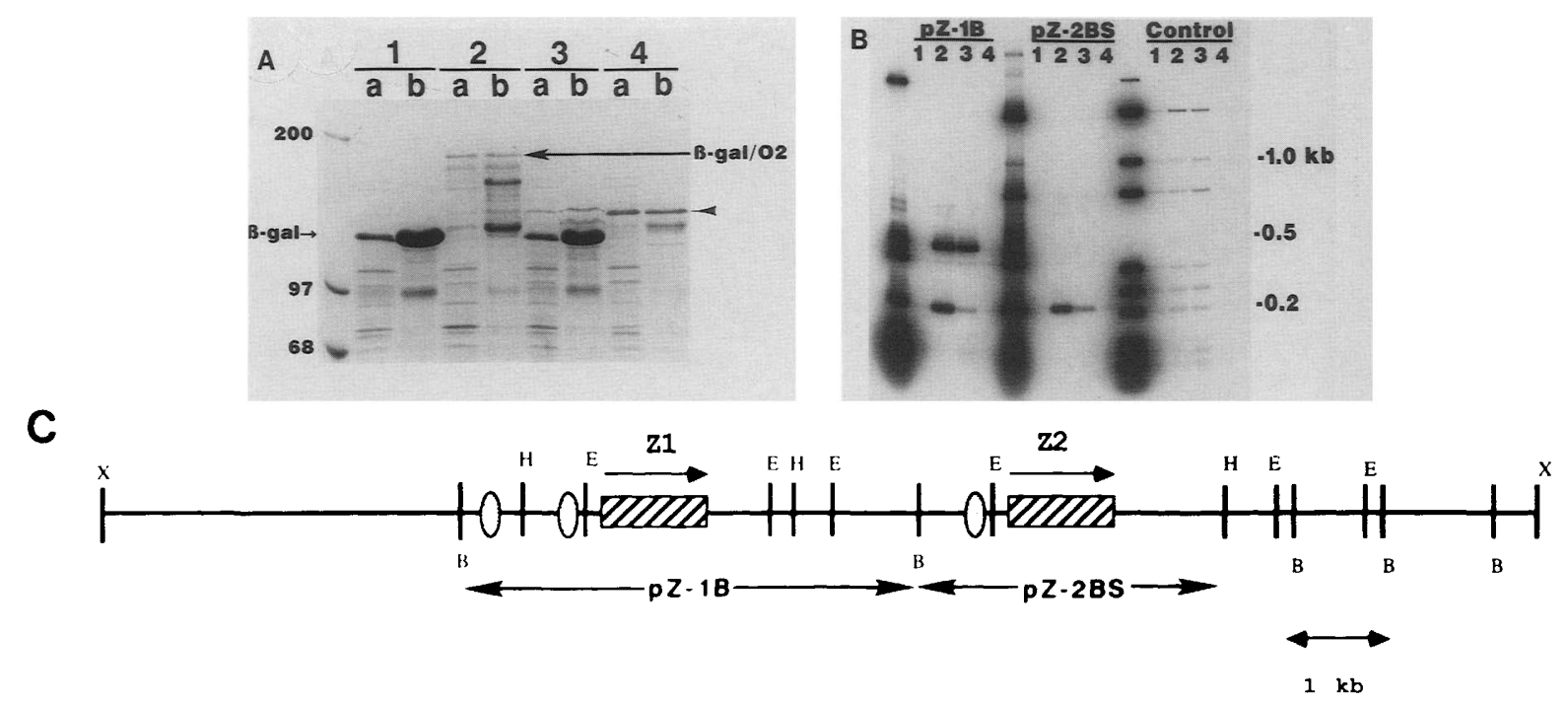

Figure 6. The DNA-binding domain in wild-type $\mathrm{O} 2$ can bind to zein promoters, whereas the corresponding domain in o2-676 cannot. (A) Bacterial expression and immunoprecipitation of the fusion proteins. E. coli that contain the plasmid expressing $\beta$-galactosidase ( $\beta$-gal) alone (lanes 1), the $\beta$-gal/O2 fusion construct (lanes 2), the $\beta$-gal/O2 bZIP fusion construct (lanes 3), or the $\beta$-gal/o2-676 bZIP fusion construct (lanes 4) were induced with IPTG and harvested 2-3 hr later for analysis. (Lanes $a$ ) Crude whole cell lysates; (lanes $b$ ) proteins obtained by immunoprecipitation with antibodies to $\beta$-galactosidase and affinity to protein A-Sepharose. An amount of protein equivalent to that present in lanes $b$ was used in the DNA-binding assays shown in $B$. The proteins generated by the bZIP fusions are indicated by the arrowhead. Molecular mass markers are indicated at left. $(B)$ DNA-binding assays. Binding reactions utilized zein genomic subclones $\mathrm{pZ}-1 \mathrm{~B}$ or $\mathrm{pZ}-2 \mathrm{BS}|C|$, or a control vector containing $1.5 \mathrm{~kb}$ of nonzein maize DNA. Shown are results of the assay with immunoprecipitates from $\beta$-gal alone (lanes 1), the $\mathrm{O} 2$ fusion protein (lanes 2), the O2 bZIP fusion protein (lanes 3), or the $02-676$ bZIP fusion protein (lanes 4). The first unnumbered lane in each set shows the labeled Sau3AI digests of the respective plasmids used in the binding assay. Relative size markers are indicated at right. A subset of the data reported here, namely the binding of pZ-1B by the O2 and O2 bZIP fusion proteins, was reported previously in Schmidt et al. (1990). (C) Restriction map of the 14-kb XhoI genomic clone (Schmidt et al. 1990), containing a tandem arrangement of two 22-kD zein genes, designated Z1 and Z2. Subclones of fragments containing each of these genes, pZ-IB and pZ-2BS, are indicated below the map with arrows. Sites bound by O2 are shown as shaded ovals. The zein-coding sequences are indicated as hatched boxes, with an arrow above showing the direction of transcription. The labels B, E, H, and X represent restriction sites for BamHI, EcoRI, HindIII, and XhoI, respectively.

carrier DNA (data not shown), even in combination with low $(20 \mathrm{~mm}) \mathrm{NaCl}$. Nonspecific binding, a property associated with all DNA-binding proteins, was not observed with 02-676 unless the nonspecific carrier DNA was lowered to $1 \mu \mathrm{g} / \mathrm{ml}$ and $\mathrm{NaCl}$ concentrations were reduced to $20 \mathrm{~mm}$.

\section{Discussion}

Site-directed mutagenesis experiments on the basic regions of the mammalian bZIP proteins Fos, Jun, C/EBP, and CREB have delineated important residues in this domain for DNA-binding activity. In most cases, blocks of two or more residues were substituted or deleted, which reduced or eliminated DNA-binding activity (Kouzarides and Ziff 1988; Gentz et al. 1989; Landschulz et al. 1989; Neuberg et al. 1989; Turner and Tiian 1989; Dwarki et al. 1990). Substitutions at individual amino acids in the basic region have generally been of an extreme nature (Gentz et al. 1989; Neuberg et al. 1989; Dwarki et al. 1990; Ransone et al. 1990). For example, basic residues have been replaced by uncharged or acidic residues, producing alterations in DNA binding of variable severity. One possible interpretation of these results is that the overall distribution of positive charge within the basic domain is an important component of DNA binding by bZIP proteins. Nevertheless, it is unclear from these previous studies which specific residues within the basic domain are truly critical for the recognition of DNA target sites by bZIP proteins, since all single-site substitutions that abolished function in these studies were nonconservative changes. We have identified two amino acids in the basic region of the bZIP protein Opaque-2 that appear to be essential to its DNA-binding activity. Conservative amino acid substitutions at either the invariant arginine or the invariant asparagine result in a complete loss of detectable DNA binding by the $\mathrm{O} 2$ protein. Because of the complete conservation of these residues within the bZIP protein family, it is quite likely that they play a key role in the general DNA-binding properties of the bZIP motif.

The in vivo-generated substitution of lysine for arginine in the $02-676$ protein is a very conservative change, yet it results in complete loss of DNA binding in vitro. One might expect that basic residues such as arginine and lysine would be interchangeable to some degree in the basic region since the overall charge of the region would be maintained. Indeed, all of the other basic 


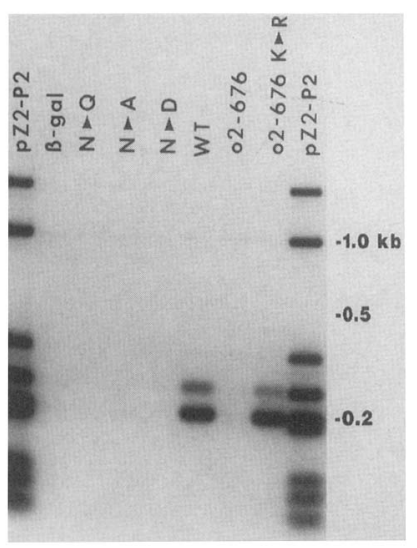

Figure 7. DNA-binding analysis of site-directed mutants of $\mathrm{O} 2$ and $02-676$. The binding assay utilized plasmid pZ2-P2, which consists of a Bluescript KS vector containing the O2-binding site within a 200-bp Sau3AI fragment of the Z2 zein promoter (see Fig. 6C). The flanking lanes show the labeled Sau3AI fragments of pZ2-P2 DNA used in the binding reaction. The inner lanes are results of incubating pZ2-P2 fragments with one of several $\beta$-gal fusion proteins: $\beta$-gal alone, $\mathrm{O} 2$ fusion containing substitutions at the invariant asparagine (N-Q, N-A, N-D), wild-type O2 fusion (WT), 02-676 fusion (02-676), $02-676$ lysine to arginine fusion (02-676 K-R). Approximately equal amounts of each fusion protein were used in the DNA-binding assay. Relative size markers are indicated at right. The upper fragment of the two fragments retained by wild-type and $02-676 \mathrm{~K}-\mathrm{R}$ arises from a mobility shift of the 200-bp zein target fragment due to incomplete phenol extraction of the proteins bound to it.

amino acids within the basic domain are incompletely conserved among the bZIP proteins, suggesting either that any protein-DNA contacts made by these residues can be accomplished by either arginine or lysine or that these residues are functioning separately in each different bZIP protein to make sequence-specific contacts with the respective DNA target site of each bZIP protein. Systematic substitutions of arginine for lysine and vice versa have not been performed on any bZIP protein to determine the effects of such subtle changes.

The invariant arginine may make a contribution to nonspecific binding. The wild-type $\mathrm{O} 2$ protein binds nonspecifically to DNA as the salt concentration is lowered, whereas the $02-676$ protein does not bind at all under these conditions (Fig. 8). Clearly, the arginine-tolysine substitution in $02-676$ has not only affected the protein's ability to specifically bind to its target sequence but the mutation reduced dramatically the nonspecific DNA-binding activity that the wild-type $\mathrm{O} 2$ protein, like most DNA binding proteins, has as a component of its total activity. This result, and the fact that the substituted arginine is completely conserved among the bZIP proteins, suggests that this residue is performing a more general role in DNA binding than the other basic residues in the bZIP domain and that it may make a large contribution to the nonspecific DNA binding component in particular.

Subtle changes at the invariant asparagine in the basic region of $\mathrm{O} 2$ resulted in complete loss of binding to the target sequence, suggesting that this residue, like the invariant arginine, is essential for DNA-binding activity. Recently, Vinson and collegues (1989) have proposed that the invariant asparagine functions to angulate the basic regions of each helical bZIP domain in the dimeric protein, thus allowing the two DNA-binding domains to wrap around the major groove of the DNA double helix. The formation of this "scissors-grip" structure presumably provides added stability to the protein-DNA complex. Other amino acids besides asparagine at this position presumably would not angulate the helical basic domain correctly, and thus stable binding would not occur (Vinson et al. 1989).

Because the 02-676 protein does not bind DNA in vitro, the substitution of lysine for the invariant arginine in the $02-676$ gene product is most likely the lesion that gives rise to the reduced zein gene expression observed for $02-676$ in vivo. The restoration of the wild-type sequence by site-specific mutagenesis in $02-676$, leading to the restoration of binding activity, argues that the Gto-A transition in the bZIP domain of o2-676 is the only significant change with regard to DNA binding. However, we cannot rule out other sequence changes in o2676 that may have occurred outside of the bZIP domain, but within some other unknown domain that is critical for zein activation.

Although mutations at 02 primarily impact the expression of the $22-\mathrm{kD}$ class of zeins, some members of the $19-\mathrm{kD}$ zein class are affected as well in the $02-R$ and $02-676$ mutants (Fig. 2). Particularly surprising is that some of the $19-\mathrm{kD}$ zeins appear to be affected more severely by the $02-676$ mutation than are some of the 22 $\mathrm{kD}$ zeins. This is especially noticeable in $\mathrm{R} 802$ and, to a lesser extent, in W22. For at least one member of the $19-\mathrm{kD}$ zeins this effect is observable at the level of gene transcription (Fig. 3). In $02-676$ endosperms the levels of B41 transcript are affected more severely than they are in

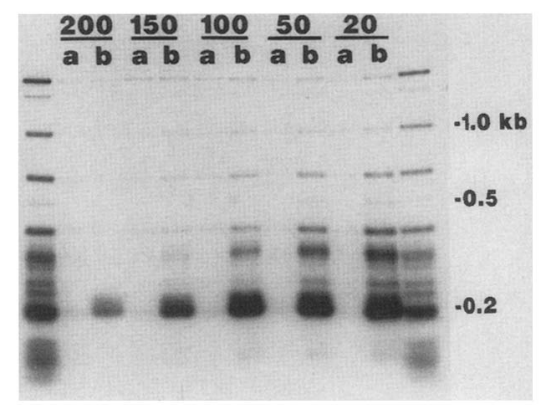

Figure 8. The effects of decreasing $\mathrm{NaCl}$ concentrations on the DNA binding of $\mathrm{O} 2$ and $02-676$ fusion proteins. Numbers above each pair of lanes refer to the millimolar concentration of $\mathrm{NaCl}$ used in the binding assay. Fragments retained by the o2-676 fusion protein or the $\mathrm{O} 2$ fusion protein are shown in lanes $a$ and $b$, respectively. The flanking lanes show the labeled fragments from a Sau3AI digest of pZ2-P2 (legend to Fig. 7). Twice as much total DNA was loaded in the left flanking lane, compared with the right. Relative size markers are indicated at right. 
$02-R$ endosperms. However, B41 may be atypical of the $19-\mathrm{kD}$ zeins (Rubenstein and Geraghty 1986) and may not be reflective of this class as a whole. On the basis of a comparison of cDNA sequence information, Rubenstein and Geraghty (1986) have placed B4l in a small subfamily of $19-\mathrm{kD}$ zeins consisting of one other member, B59. When another zein cDNA encoding a $19-\mathrm{kD}$ zein protein (B54) is used as a probe, no significant difference is observed in the levels of transcript present in the $02-676$ and $02-R$ endosperms (Fig. 3). Also, three other 19-kD zein probes, B20, B36, and A30 (Burr et al. 1982), showed little or no difference in the levels of transcript between $02-R$ and $02-676$, even though both genotypes showed a reduction in transcript levels relative to wild type (data not shown). The exact role that $\mathrm{O} 2$ may play in the expression of the $19-\mathrm{kD}$ class is not clear. We have been unable to demonstrate binding of $\mathrm{O} 2$ to $19-\mathrm{kD}$ zein gene promoters (belonging to the same subfamily of $19-\mathrm{kD}$ zeins as B54) in our in vitro-binding assays (G. Hoscheck and R.J. Schmidt, unpubl.).

The inability of the $02-676$ protein to bind $22-\mathrm{kD}$ zein gene promoters in vitro suggests that it also should not be able to bind zein promoters in vivo. If this were the case, we would expect the expression pattern of the zeins in the $02-676$ mutant to be very similar to that seen in the $02-R$ allele. This is not the case; members of the $22-\mathrm{kD}$ zein class are expressed in $02-676$, whereas they are completely absent in the 02 null (see Fig. 2). The reason for this apparent inconsistency between the in vivo and in vitro observations is not clear. It is possible that our in vitro assay is not sensitive enough to detect weak but selective interactions of the $02-676$ protein with the zein target fragment. These interactions may be sufficient in vivo to partially activate the zein genes. It is also possible that the $02-676$ protein-DNA complex is somehow stabilized in vivo by other maize proteins not present in our in vitro assay.

Another explanation to account for the levels of zein gene expression observed in vivo with the failure to detect DNA binding in vitro is to suppose that $02-676$ land $\mathrm{O} 2$ ) binds to zein promoters as a heterodimer with another bZIP protein in vivo. The mammalian bZIP protein Jun, for example, can bind to its target site as a homodimer but binds this site with a higher affinity as a heterodimer with another bZIP protein, Fos (Halazonetis et al. 1988; Rauscher et al. 1988; Smeal et al. 1989|. Recently, other examples of bZIP protein heterodimers have been elucidated (Hai et al. 1989; Benbrook and Jones 1990). In the $02-676$ mutant, this heterodimer formation might partially compensate for the DNA-binding defect of the o2-676 protein by providing one bZIP motif that retains the invariant arginine residue. This o2-676bZIP-X heterodimer might be able to associate weakly with the zein target site and thus facilitate the partial activation of the zein genes that we observe in vivo for 02.676 . It is known that other loci regulate zein gene expression, among them opaque-7 and floury-2. Although the gene products of these loci have not been isolated, they may encode proteins that form heterodimers with $\mathrm{O} 2$. Heterodimer formation of the $02-676$ product with one or more proteins might account for both the presence of some $22-\mathrm{kD}$ zeins and the reduction in at least some members of the $19 \cdot \mathrm{kD}$ class.

We have demonstrated here and elsewhere /Schmidt et al. 1990 ) that O2 binds to the promoter of $22-\mathrm{kD}$ zein genes. The arginine to lysine mutation in the bZIP domain of $02-676$ affects recognition of the zein target sequence by the mutant protein and results in differential expression of members of the zein multigene family. This argues strongly in favor of a model in which $\mathrm{O} 2$ regulates zein gene transcription by direct interaction with zein gene promoters and not by the induction of the synthesis of an intermediary regulatory molecule, as has been suggested by others (Soave et al. 1981; Di Fonzo et al. 1988).

\section{Materials and methods}

Mutant isolations

The $02-R$ allele occurred as a spontaneous mutation in maize inbred W64A (W.R. Singleton and D.F. Jones, unpubl.). This allele, backcrossed into maize inbred W22, was characterized previously as a null allele based on the absence of any detectable O2 message by Northern analysis (Schmidt et al. 1987). We screened a large collection of M2 ears from EMS mutagenesis at the University of Missouri that were provided by M.G. Neuffer (Neuffer and Sheridan 1980). We selected 138 nonlethal opaque mutants for further examination. An additional 12 opaque mutants generated at Brookhaven were also screened. Seed from each segregating population of opaque mutants were analyzed for zein protein by one-dimensional SDS-PAGE. In one mutant from the Missouri material, 676 , the $19-\mathrm{kD}$ zeins appeared to be affected more significantly than the $22-\mathrm{kD}$ zeins.

\section{Zein protein analyses}

Mature kernels were soaked in water for $10 \mathrm{~min}$ to loosen pericarp from the endosperm. After removal of the pericarp and embryo, endosperms were first ground in an electric coffee mill and then pulverized to a fine powder with mortar and pestle. The ground endosperm meal was sifted through a $250-\mu \mathrm{m}$ screen. The portion passing through the screen was stored in a desiccator under vacuum for $24 \mathrm{hr}$ prior to extracting zein proteins. For each of at least three independent determinations, 0.4 or 0.5 grams of meal was extracted with $5 \mathrm{ml}$ of $70 \%$ ETOH for $0.5 \mathrm{hr}$ with frequent vortexing. The contents were then centrifuged at $15,000 \mathrm{~g}$ for $15 \mathrm{~min}$ at $4^{\circ} \mathrm{C}$. The supernatant was transferred carefully into dialysis tubing and dialyzed for $15 \mathrm{hr}$ against several changes of deionized water. The contents of the dialysis bag, now containing precipitated zein proteins, was lyophilized to remove the water. Following lyophilization the zein protein was weighed and stored at $4^{\circ} \mathrm{C}$. Two-dimensional IEF/SDS/PAGE (O'Farrell 1975) was performed using ampholytes of $\mathrm{pH}$ 6-8 in the first dimension and $15 \%$ polyacrylamide $/ 0.1 \%$ SDS in the second dimension. Gels from the first dimension were equilibrated for a minimum of $1 \mathrm{hr}$ in a solution of $62.5 \mathrm{~mm}$ Tris $(\mathrm{pH} 6.8), 10 \%$ glycerol, $5 \% \beta$-mercaptoethanol, and $0.004 \%$ bromophenol blue before mounting on the second-dimension SDS gel. First-dimension tube gels were loaded with $50 \mu \mathrm{g}$ of zein proteins extracted from kernels homozygous for the normal $\mathrm{O} 2$ allele, and $25 \mu \mathrm{g}$ of zein protein from kernels homozygous for the 02 mutant alleles. Because there are fewer zein proteins present in the mutants, it was 
necessary to use less protein to prevent overloading of the gel and loss of resolution.

\section{Fusion proteins}

Construction of the $\beta$-gal/O2 and the $\beta$-gal/O2 bZIP fusion proteins was described previously (Schmidt et al. 1990). The $\beta$-gal/o2-676 fusion construct was generated by digesting the o2-676 cDNA in Bluescript SK with ApaI, which cuts at nucleotide +38 in $O 2$ (Schmidt et al. 1990), and $X b a l$, which cuts in the 3'-polylinker sequence, gel-purifying the $1.4-\mathrm{kb}$ Apal/XbaI fragment and blunt-ending with the Klenow fragment of DNA polymerase I. HindIII linkers were ligated to the ends, and the fragment was cloned into the HindIII site of the lacZ bacterial expression vector pUR288 (Rüther and Müller-Hill 1983). The resultant $\beta$-gal/o2-676 fusion protein, like the $\beta$-gal/O2 fusion described previously (Schmidt et al. 1990), contains all but the first 13 amino acids of the $02-676$ protein. The $\beta$-gal/o2-676 bZIP construct was made in a similar fashion, except that a StuI/SalI digest was used to isolate an internal $0.3-\mathrm{kb}$ fragment of the 02-676 cDNA (nucleotides 571-855 of O2) that was cloned into pUR288. Because the o2-676 cDNA contained a polymorphism that destroyed the PstI site present in the O2 cDNA (nucleotide 566), we were unable to fuse the $02-676$ fragment to $\operatorname{lac} Z$ at the same codon as was done for the O2 bZIP construct (Schmidt et al. 1990). The Stul site lies 4 bp to the 3' side of the PstI site; thus, the o2-676 bZIP construct presumably would be lacking one codon at the $\beta$-gal/02-676 junction, relative to the $\mathrm{O} 2 \mathrm{bZIP}$ construct. Upon sequencing the junction between $1 a c Z$ and $02-676$ in the $02-676$ bZIP fusion construct, we discovered a 9-bp deletion that removed an additional three amino acids of the $02-676$ moiety, such that the $02-676 \mathrm{bZIP}$ protein is shortened by four amino acids relative to the O2 bZIP fusion construct. This deletion lies 3.3 residues amino-terminal of the actual bZIP domain. Since the $02-676$ fusion protein, which obviously contains these four amino acids, does not bind the zein target sequence, we conclude that the deletion of these four residues in the $02-676 \mathrm{bZIP}$ fusion is not responsible for the DNA-binding defect observed for the $02-676$ bZIP protein.

\section{DNA-binding assay}

Fusion proteins were expressed in E. coli and partially purified by immunoprecipitation with antibodies to $\beta$-galactosidase, essentially as described (Schmidt et al. 1990). An aliquot of the immunoprecipitate containing the bound fusion protein was boiled for $5 \mathrm{~min}$ in SDS loading buffer before electrophoresis on $7.5 \%$ polyacrylamide/0.1\% SDS gels (Laemmli 1970). To assay for DNA binding, an amount of the immunoprecipitated fusion protein equivalent to that analyzed on the protein gel was resuspended in $40 \mu \mathrm{l}$ of DNA-binding buffer $150 \mathrm{mM} \mathrm{NaCl}, 1 \mathrm{~mm}$ EDTA, $1 \mathrm{~mm}$ DTT, $50 \mathrm{~mm}$ Tris- $\mathrm{HCl}\langle\mathrm{pH} 7.8 \|$ plus $0.1 \mathrm{mg} / \mathrm{ml}$ salmon sperm DNA. Approximately $40 \mathrm{ng}$ of a ${ }^{32} \mathrm{P}$-labeled Sau3AI digest of plasmid DNA containing the 200-bp zein target fragment was then added. Incubation, washing, and processing of the retained fragments were performed as described previously (Schmidt et al. 1990). This assay is a modification of the original assay described by McKay (1981). For testing the effect of lowering $\mathrm{NaCl}$ concentration on DNA binding, the incubation and washing steps were carried out in binding buffers adjusted to the various $\mathrm{NaCl}$ concentrations indicated in Figure 8 .

\section{Site-directed mutagenesis}

To create the 02-676 K-R fusion construct, the $02-676$ fusion construct was digested with HindIII, and the 1.4-kb $02-676$
cDNA fragment was isolated and inserted into the Bluescript SK vector (Stratagene). Next, $50 \mu \mathrm{l}$ of an overnight culture of XL1Blue bacteria (Stratagene) containing this plasmid was infected with $\sim 10^{12}$ pfu of helper phage R408 and subsequently was diluted into $3 \mathrm{ml} 2 \mathrm{XYT}(1.6 \%$ tryptone, $1.0 \%$ yeast extract, $0.5 \% \mathrm{NaCl})+0.1 \%$ glucose $+50 \mu \mathrm{g} / \mathrm{ml}$ carbenicillin. Following 1-2 days of incubation, single-stranded DNA was purified according to the protocol described in the Amersham version 2 oligonucleotide-directed in vitro mutagenesis kit, except that PEG precipitations were carried out in $3.5 \mathrm{M} \mathrm{NH}_{4} \mathrm{Ac}$ instead of $2.5 \mathrm{M} \mathrm{NaCl}$. A 22-bp oligonucleotide specifying the K-R substitution was annealed to the single-stranded DNA template, and all subsequent mutagenesis steps were performed with the Amersham kit, according to the provided protocol. Mutant clones were screened by dideoxy sequencing, and a clone with the correct $\mathrm{K}-\mathrm{R}$ codon substitution was digested with HindIII to shuttle the 1.4-kb o2-676 K-R fragment back into pUR288. The three mutants at the invariant asparagine, N-Q, N-A, and N-D, were generated in a similar fashion, except that the $1.4-\mathrm{kb} \mathrm{O} 2$ fragment was subcloned into the Bluescript vector instead of the 02-676 fragment. All three asparagine mutant constructs were sequenced from the PstI site to the SalI site (nucleotides 566855 of O2) to ensure that no changes other than the desired one had occurred within the bZIP domain.

\section{RNA analyses}

Each slot of the RNA slot blots (Schleicher \& Schuell Minifold II) was loaded with a sample of total RNA in $400 \mu 1$ of $13.5 \%$ formaldehyde, $7.5 \times$ SSC, $5 \mu \mathrm{g}$ of salmon sperm DNA after incubating at $65^{\circ} \mathrm{C}$ for $15 \mathrm{~min}$. Equivalent amounts of mRNA, as determined by hybridization to pvu55 (Burr and Burr 1982a), were loaded for each genotype. Following the application of RNA each sample was washed with $400 \mu \mathrm{l}$ of $10 \times$ SSC and dried in a vacuum oven at $80^{\circ} \mathrm{C}$. Hybridizations were performed at $55^{\circ} \mathrm{C}$ in $50 \%$ formamide as described previously (Schmidt et al. 1987). The 02 RNA blot analysis was performed as described in Schmidt et al. (1987), except that the O2 probe was a $0.6-\mathrm{kb}$ EcoRI fragment from the 3 ' end of the O2 cDNA /Schmidt et al. 1990), and the probes were labeled by the random priming method (Feinberg and Vogelstein 1983).

\section{Bacterial strains, cDNA, and DNA clones}

E. coli strain JM109 was used to express all of the fusion proteins described. XL1-Blue (Stratagene) was used to generate single-stranded DNA templates for site-directed mutagenesis. The 02-676 cDNA was isolated from a library constructed from 22day-old endosperms of inbred R802 that were homozygous for the $02-676$ allele. The cDNA clones were identified by screening the library with O2-specific probes, as described in Schmidt et al. (1990) for the cloning of the normal allele of O2. Isolation of the zein genomic clone was described previously (Schmidt et al. 1990). Plasmids pZ-1B and pZ-2BS were generated by subcloning the $4.5-\mathrm{kb}$ BamHI fragment and the $3.5-\mathrm{kb}$ BamHI-SalI fragment, respectively, into Bluescript KS. These clones are indicated on the genomic map in Figure 6C; the Sall site, which is not indicated, lies adjacent to the 3' HindIII site. pZ2-P2 was generated by subcloning a 200-bp Sau3AI fragment of pZ-2BS that contains the $\mathrm{O} 2$-binding site into Bluescript KS. All sequencing was performed by the dideoxy method using the Sequenase enzyme (U.S. Biochemical).

\section{Acknowledgments}

We thank Dr. M. G. Neuffer for providing the EMS-induced mutants and Dr. K. Cone for providing the cDNA library. Re- 
search support at the University of California, San Diego, was provided to M.J.A. by a Predoctoral Fellowship on National Insitutes of Health (NIH) grant GM07313 to Dr. D.L. Lindsley, and to R.J.S. by NIH grant GM41286 and the Powell Foundation. Research at Brookhaven National Laboratory (BNL) was provided by NIH grant GM31093 and by the Office of Basic Energy Sciences of the U.S. Department of Energy. At BNL, R.J.S. was supported by an National Science Foundation postdoctoral fellowship in plant molecular biology (PCM-8412395).

The publication costs of this article were defrayed in part by payment of page charges. This article must therefore be hereby marked "advertisement" in accordance with 18 USC section 1734 solely to indicate this fact.

\section{References}

Angel, P., E.A. Allegretto, S.R. Okino, K. Hattori, W.J. Boyle, T. Hunter, and M. Karin. 1988. Oncogene jun encodes a sequence-specific trans-activator similar to AP-1. Nature 332: $166-171$.

Benbrook, D.M. and N.C. Jones. 1990. Heterodimer formation between CREB and JUN proteins. Oncogene 5: 295-302.

Brown, J.W.S., C. Wandelt, and G. Feix. 1986. The upstream regions of zein genes: Sequence analysis and expression in the unicellular green alga Acetabularia. Eur. I. Cell Biol. 42: $161-170$.

Burr, B. and F.A. Burr. 1982a. Ds controlling elements of maize at the Shrunken locus are large and dissimilar insertions. Cell 29: 977-986.

—_. 1982b. Three mutations in Zea mays affecting zein accumulation: A comparison of zein polypeptides, in vitro synthesis and processing, mRNA levels, and genomic organization. I. Cell Biol. 94: 201-206.

Burr, B., F.A. Burr, T.P. St. John, M. Thomas, and R.W. Davis. 1982. Zein storage protein gene family of maize. /. Mol. Biol. 154: $33-49$.

Cohen, T.R. and T. Curran. 1988. fra-1: A serum-inducible, cellular immediate-early gene that encodes a fos-related antigen. Mol. Cell. Biol. 8: 2063-2069.

Desplan, C., J. Theis, and P.H. O'Farrell. 1985. The Drosophila developmental gene, engrailed, encodes a sequence-specific DNA binding activity. Nature 318: 630-635.

Di Fonzo, N., H. Hartings, M. Brembilla, M. Motto, C. Soave, E. Navarro, J. Palau, W. Rhode, and F. Salamini. 1988. The b-32 protein from maize endosperm, an albumin regulated by the O2 locus: Nucleic acid (cDNA) and amino acid sequences. Mol. Gen. Genet. 212: 481-487.

Dwarki, V.J., M. Montminy, and I.M. Verma. 1990. Both the basic region and the "leucine zipper" domain of the cyclic AMP response element binding (CREB) protein are essential for transcriptional activation. EMBO J. 9: 225-232.

Feinberg, A.P. and B. Vogelstein. 1983. A technique for radiolabeling DNA restriction endonuclease fragments to high specific activity. Anal. Biochem. 132: 6-13.

Gentz, R., F.J. Rauscher III, C. Abate, and T. Curran. 1989. Parallel association of Fos and Jun leucine zippers juxtaposes DNA binding domains. Science 243: 1695-1699.

Gianazza, E., P.G. Righetti, F. Pioli, E. Galante, and C. Soave. 1976. Size and charge heterogeneity of zein in normal and opaque-2 maize endosperms. Maydica 21: 1-17.

Gonzalez, G.A., K.K. Yamamoto, W.H. Fischer, D. Karr, P. Menzel, W. Biggs III, W.W. Vale, and M.R. Montminy. 1989. A cluster of phosphorylation sites on the cyclic AMP-regulated nuclear factor CREB predicted by its sequence. Nature 337: 749-752.
Hagen, G. and I. Rubenstein. 1980. Two-dimensional gel analysis of the zein proteins in maize. Plant Sci. Lett. 19: 217223.

Hai, T.W., F. Liu, W.J. Coukos, and M.R. Green. 1989. Transcription factor ATF cDNA clones: an extensive family of leucine zipper proteins able to selectively form DNA-binding heterodimers. Genes ef Dev. 3: 2083-2090.

Halazonetis, T.D., K. Georgopoulos, M.E. Greenberg, and P. Leder. 1988. c-Jun dimerizes with itself and with c-Fos, forming complexes of different DNA binding affinities. Cell 55: 917924.

Hartings, H., M. Maddaloni, N. Lazzaroni, N. Di Fonzo, M. Motto, F. Salamini, and R. Thompson. 1989. The O2 gene which regulates zein deposition in maize endosperm encodes a protein with structural homologies to transcriptional activators. EMBO J. 8: 2795-2801.

Heidecker, G. and J. Messing. 1986. Structural analysis of plant genes. Annu. Rev. Plant Physiol. 37: 439-466.

Hinnebusch, A.G. 1984. Evidence for translational regulation of the activator of general amino acid control in yeast. Proc. Natl. Acad. Sci. 81: 6442-6446.

Katagiri, F., E. Lam, and N.H. Chua. 1989. Two tobacco DNAbinding proteins with homology to the nuclear factor CREB. Nature 340: 727-730.

Kodrzycki, R., R.S. Boston, and B.A. Larkins. 1989. The opaque2 mutation of maize differentially reduces zein gene transcription. Plant Cell 1: 105-114.

Kouzarides, T. and E. Ziff. 1988. The role of the leucine zipper in the fos-jun interaction. Nature 336: 646-651.

Kridl, J.C., J. Vieira, I. Rubenstein, and J. Messing. 1984. Nucleotide sequence analysis of a zein genomic clone with a short open reading frame. Gene 28: 113-118.

Laemmli, U.K. 1970. Cleavage of structural proteins during the assembly of the head of bacteriophage T4. Nature 227: 680685.

Landschulz, W.H., P.F. Johnson, and S.L. McKnight. 1988a. The leucine zipper: A hypothetical structure common to a new class of DNA binding proteins. Science 240: 1759-1764.

-1989. The DNA binding domain of the rat liver nuclear protein C/EBP is bipartite. Science 243: 1681-1688.

Landschulz, W.H., P.F. Johnson, E.Y. Adashi, B.J. Graves, and S.L. McKnight. 1988b. Isolation of a recombinant copy of the gene encoding C/EBP. Genes 4 Dev. 2: 786-800.

Langridge, P. and G. Feix. 1983. A zein gene of maize is transcribed from two widely separated promoter regions. Cell 34: 1015-1022.

Laughon, A., W. Howell, and M.P. Scott. 1988. The interaction of proteins encoded by Drosophila homeotic and segmentation genes with specific DNA sequences. Development (suppl.) 104: 75-83.

McKay, R. 1981. Binding of a simian virus $40 \mathrm{~T}$-antigen related protein to DNA. I. Mol. Biol. 145: 471-488.

Mertz, E.T., L.S. Bates, and O.E. Nelson. 1964. Mutant gene that changes protein composition and increases lysine content of maize endosperm. Science 145: 279-280.

Motto, M., M. Maddaloni, G. Ponziani, M. Brembilla, R. Marotta, N. Di Fonzo, C. Soave, R. Thompson, and F. Salamini. 1988. Molecular cloning of the $02-m 5$ allele of Zea mays using transposon marking. Mol. Gen. Genet. 212: 488494.

Nelson, O.E. 1979. Inheritance of amino acid content in cereals. In Seed protein improvement in cereals and grain legumes, vol. 1, pp. 79-88. International Atomic Energy Agency, Vienna.

Neuberg, M., M. Schuermann, J.B. Hunter, and R. Müller. 1989. Two functionally different regions in Fos are required for the 
sequence-specific DNA interaction of the Fos/Jun protein complex. Nature 338: 589-590.

Neuffer, M.G. and W.F. Sheridan. 1980. Defective kernel mutants of maize. Genetics 95: 929-944.

O'Farrell, P.H. 1975. High resolution two-dimensional electrophoresis of proteins. J. Biol. Chem. 250: 4007-4021.

Paluh, J.L., M.J. Orbach, T.L. Legerton, and C. Yanofsky. 1988. The cross-pathway control gene of Neurospora crassa, $c p c-1$, encodes a protein similar to GCN4 of yeast and the DNAbinding domain of the oncogene v-iun-encoded protein. Proc. Natl. Acad. Sci. 85: 3728-3732.

Prendergast, G.C. and E.B. Ziff. 1989. DNA-binding motif. Nature 341: 392.

Ransone, L.J., J. Visvader, P. Wamsley, and I.M. Verma. 1990. Trans-dominant negative mutants of Fos and Jun. Proc. Natl. Acad. Sci. 87: 3806-3810.

Rauscher, F.J. III, P.J. Voulalas, B.R. Franza, Jr., and T. Curran. 1988. Fos and Jun bind cooperatively to the AP-1 site: Reconstitution in vitro. Genes \& Dev. 2: 1687-1699.

Rubenstein, I. and D.F. Geraghty. 1986. The genetic organization of zein. In Advances in cereal science and technology |ed. Y. Pomeranz), pp. 297-315. American Association of Cereal Chemists, Saint Paul, Minnesota.

Rüther, U. and B. Müller-Hill. 1983. Easy identification of cDNA clones. EMBO I. 2: 1791-1794.

Ryder, K., L.F. Lau, and D. Nathans. 1988. A gene activated by growth factors is related to the oncogene $v$-jun. Proc. Natl. Acad. Sci. 85: 1487-1491.

Schmidt, R.J., F.A. Burr, and B. Burr. 1987. Transposon tagging and molecular analysis of the maize regulatory locus opaque-2. Science 238: 960-963.

Schmidt, R.J., F.A. Burr, M.J. Aukerman, and B. Burr. 1990. Maize regulatory gene opaque-2 encodes a protein with a "leucine-zipper" motif that binds to zein DNA. Proc. Natl. Acad. Sci. 87: 46-50.

Smeal, T., P. Angel, 1. Meek, and M. Karin. 1989. Different requirements for formation of Jun : Jun and Jun : Fos complexes. Genes \&) Dev. 3: 2091-2100.

Soave, C., I. Tardani, N. Di Fonzo, and F. Salamini. 1981. Regulation of zein level in maize endosperm by a protein under control of the opaque-2 and opaque-6 loci. Cell 27: 403-410.

Soave, C., P.G. Righetti, C. Lorenzoni, E. Gentinetta, and F. Salamini. 1976. Expressivity of the opaque-2 gene at the level of zein molecular components. Maydica 21: 61-75.

Spena, A., A. Viotti, and V. Pirrotta. 1982. A homologous repet itive block structure underlies the heterogeneity of heavy and light chain zein genes. EMBO J. 1: 1589-1594.

Tabata, R., H. Takase, S. Takayama, K. Mikami, A. Nakatsuka, T. Kawata, T. Nakayama, and M. Iwabuchi. 1989. A protein that binds to a cis-acting element of wheat histone genes has a leucine zipper motif. Science 245: 965-967.

Turner, R. and R. Tjian. 1989. Leucine repeats and an adjacent DNA binding domain mediate the formation of functional cFos-cJun heterodimers. Science 243: 1689-1694.

Van Straaten, F., R. Muller, T. Curran, C. van Beveren, and I.M. Verma. 1983. Complete nucleotide sequence of human c-onc gene: Deduced amino acid sequence of the human c-fos protein. Proc. Natl. Acad. Sci. 80: 3183-3187.

Vinson, C.R., P.B. Sigler, and S.L. McKnight. 1989. Scissors-grip model for DNA recognition by a family of leucine zipper proteins. Science 246: 911-916. 


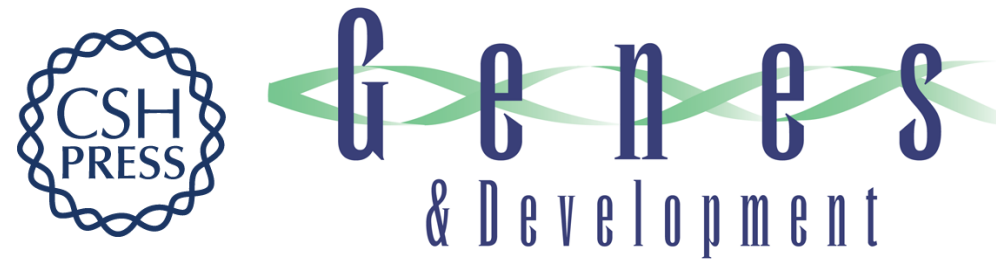

\section{An arginine to lysine substitution in the bZIP domain of an opaque-2 mutant in maize abolishes specific DNA binding.}

M J Aukerman, R J Schmidt, B Burr, et al.

Genes Dev. 1991, 5:

Access the most recent version at doi:10.1101/gad.5.2.310

References This article cites 52 articles, 22 of which can be accessed free at:

http://genesdev.cshlp.org/content/5/2/310.full.html\#ref-list-1

License

Email Alerting

Service

Receive free email alerts when new articles cite this article - sign up in the box at the top right corner of the article or click here.

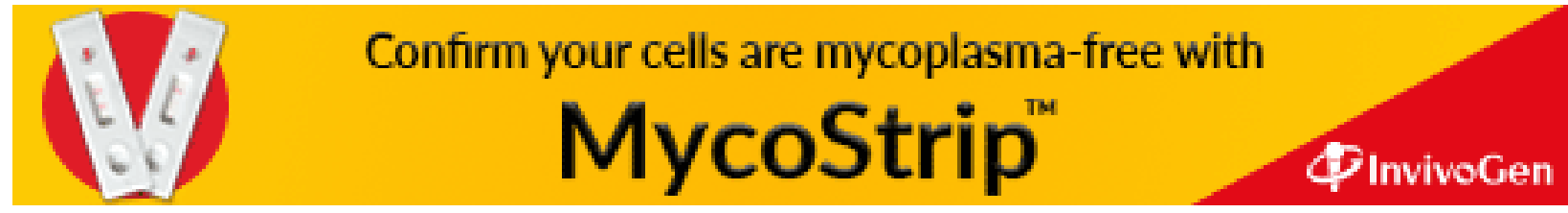

